\title{
Expanded genetic insight and clinical experience of DNMT1-complex disorder
}

Hongyan Bi, MD, Kaori Hojo, MD, Masashi Watanabe, MD, Christina Yee, MD, Kiran Maski, MD, Sadaf Saba, MS, Jonathan Graff-Radford, MD, Mary M. Machulda, PhD, Erik K. St Louis, MD, Ilona Spitsyna Humes, MD,

Eoin P. Flanagan, MB, BCh, Stefan Nicolau, MD, David T. Jones, MD, Marc C. Patterson, MD,

Suresh Kotagal, MD, Yael Raz, MD, Zhiyv Niu, PhD, Jun Li, MD, and Christopher J. Klein, MD

Neurol Genet 2020;6:e456. doi:10.1212/NXG.0000000000000456

\section{Abstract}

\section{Objective}

To report novel causal mutations, expanded clinical phenotypes, and clinical management of DNA methyltransferase 1 (DNMT1)-complex disorder.

\section{Methods}

Neurophysiologic testing, imaging, and genetic findings were summarized in clinical context for 5 cases with DNMT1-complex disorder.

\section{Results}

We identified 2 novel DNMT1 mutations (p.E510K and p.P1546A) by whole-exome sequencing (WES). Case 1 (p.E510K) presented with childhood ataxia, treatment-refractory seizures, and rapid cognitive decline in his 50s. Case 2 also had childhood onset and presented with seizures, language regression, hearing loss, narcolepsy with cataplexy symptoms, optic atrophy, sensory neuropathy, and hypogammaglobulinemia requiring IV immunoglobulin. Case 2 (p.P1546A) was identified with a de novo and the first mutation residing outside the targeting sequence domain. Case 3 (p.A570V) had paralytic asymmetric onset attacks triggered by emotionality and lasting sometimes for weeks. Neuropsychological testing showed executive dysfunction localizing to frontosubcortical and frontoparietal structures. He gradually developed left predominant brain atrophy. MRI showed T2 hyperintense lesions that enhanced on $\mathrm{T} 1$ postgadolinium images, and brain PET showed hypometabolism in atrophied regions. Case 4 (p.T497P) underwent left cochlear implant, resulting in significant hearing improvements at all tested frequencies $(250-6,000 \mathrm{~Hz})$. Case $5(\mathrm{p} . \mathrm{Y} 511 \mathrm{H})$ had profound gait ataxia with posterior column atrophy of the spinal cord and abnormal evoked potentials primarily affecting the fasciculus gracilis.

\section{Conclusions}

Broader application of WES further expands genotype-phenotype correlations of DNMT1complex disorder. Two mutations are identified with early childhood onsets. The expanded new phenotypes include asymmetric brain hemiatrophy with parenchymal gadolinium enhancement, spinal cord atrophy, prolonged cataplectic spells, and hypogammaglobulinemia. Hearing loss treatment by cochlear implantation is helpful and should be considered.

\author{
Correspondence \\ Dr. Klein \\ klein.christopher@mayo.edu
}

MORE ONLINE

o Video

From the Department of Neurology (H.B., J.G.-R., E.K.S.L., E.P.F., S.N., D.T.J., M.C.P., S.K., C.J.K.), Mayo Clinic, Rochester, MN; Department of Neurology (H.B.), Beijing Friendship Hospital, China; Division of Neuropsychiatry (K.H.), Harima Sanatorium, Hyogo, Japan; Department of Neurology (M.W.), Ehime Prefectural Central Hospital, Matsuyama, Japan; Harvard Medical School (C.Y., K.M.), Boston Children's Hospital, MA; Center for Molecular Medicine and Genetics (S.S.), School of Medicine, Wayne State University, Detroit, Ml; Department of Psychology (M.M.M.), Mayo Clinic, Rochester, MN; Atrium Health (I.S.H.), Neurosciences Institute, Concord, NC; Deapartment of Head and Neck Surgery (Y.R.), Oregon Health and Science University, Portland; Department of Laboratory Medicine and Pathology (Z.N., C.J.K.), Mayo Clinic, Rochester, MN; and Department of Neurology and Translational Neuroscience Initiative (J.L.), School of Medicine. Wayne State University, Detroit, MI. 


\section{Glossary}

ADCA-DN = autosomal dominant cerebellar ataxia deafness and narcolepsy; CADD = Combined Annotation-Dependent Depletion; CMT = Charcot-Marie-Tooth; DNMT1 = DNA methyltransferase 1; EVS = Exome Variant Server; FTD = frontotemporal dementia; HSAN1E = hereditary sensory and autonomic neuropathy with dementia and hearing loss; IVIG = IV immunoglobulin; SEP = somatosensory evoked potential; TS = targeting sequence; WES $=$ whole-exome sequencing.

DNA methyltransferase 1 , encoded by the DNMT1 gene, is the sole methyltransferase for maintaining methylation during DNA replication and DNA repair. ${ }^{1,2}$ DNA methylation is an epigenetic regulator crucial in embryonic development, imprinting and genome stability, and cell differentiation., ${ }^{3,4}$ Mutations in this gene have been identified in 2 adult-onset autosomal dominant neurodegenerative syndromes: (1) hereditary sensory autonomic neuropathy with dementia and hearing loss (HSAN1E) $)^{5}$ and (2) autosomal dominant cerebral ataxia, deafness, and narcolepsy (ADCA-DN). ${ }^{6}$

Studies have shown that a triad of stereotypic clinical features is commonly linked to both HSAN1E and ADCA-DN, including sensory predominant neuropathy, sensorineural hearing loss, and cognitive decline. ${ }^{7-9}$ Aside from the 3 core features, cases can manifest with other symptoms at varied ages, including cerebellar ataxia, narcolepsy, auditory and/or visual hallucinations, optic atrophy, myoclonic seizures, and sudden personality changes that may be labeled as a psychiatric disorder early on and later a frontotemporal dementia (FTD)-like disorder. Collectively, the wide spectrum of phenotypes due to DNMT1 mutation is termed as DNMT1-complex disorder. All cases reported to date have mutations within the targeting sequence (TS) domain of DNMT1 (exons 20 and 21). Only one case (DNMT1p.N545del) had early onset at age 8 years, and this case was also the only one who had hypogammaglobulinemia. ${ }^{10}$

Herein, we report the expansion of the phenotypic spectrum of DNMT1-complex disorders including toddler onset with immunodeficiency, brain hemiatrophy, and favorable response to cochlear implantation. In addition, 2 novel mutations were found, including 1 residing outside the TS domain of DNMT1.

\section{Methods}

Phenotypic and genotypic characterizations were performed in 5 probands from 4 American families and 1 Japanese family. Clinical features of the cases are summarized below, and the pedigrees are shown in figure 1 . Three of the 5 cases were diagnosed by whole-exome sequencing before DNMT1 was considered as the causal gene. MRI of the brain and spinal cord, PET brain imaging, sleep evaluations, and neurophysiology were all variably used to phenotype cases.

\section{Standard protocol approvals, registrations, and patient consents}

This study was approved by the Mayo Clinic Institutional Review Board. The patients were consented for this study, also for supplementary video content.

\section{Data availability}

All results are available on reasonable request.

\section{Results}

\section{Novel mutation DNMT1p.E510K: Ataxia with frequent childhood seizures and late- onset dementia}

The case had unsteady gait since early childhood. He was never able to ride a bicycle due to balance problems. At age 14 years, he first experienced generalized tonic-clonic seizures. The seizure frequency was 2-3 per year throughout childhood and young adulthood despite antiepileptic medications, which improved only after the initiation of perampanel around age 50 years. Around that time, his balance worsened with frequent falls despite using a walker and canes. At age 59 years, his ataxia worsened with frequent falls, inability to walk, needing caregiver assistance for his daily activities. In addition, alternating ankle, finger, and hand movements were uncoordinated. Neurologic and audiology examination showed severe memory impairment and moderate severe sensorineural hearing loss. He was diffusely areflexic. His nerve conduction study showed significantly reduced amplitudes with normal or minimally decreased conduction velocity, supporting a sensory axonal polyneuropathy. MRI of the brain showed diffuse brain atrophy including the superior cerebellar vermis. His condition declined rapidly, and he died at age 61 years. The case's father and father's cousin had been given the diagnosis of inherited neuropathy, but no clinical or genetic details were available. Whole-exome sequencing (WES) revealed a novel DNMT1 mutation p.E510K. This mutation is absent in large genetic databases (gnomAD, 1000 Genomes, and Exome Variant Server [EVS] $)^{11-13}$ and shows possibly damaging (PolyPhen-2), damaging (SIFT, FATHMM, and fathmm-MKL), deleterious (LRT), diseasecausing (MutationTaster) effect through in silico analysis with a Combined Annotation-Dependent Depletion (CADD) score of 23.8. ${ }^{14-16}$ This variant is classified as pathogenic variant. ${ }^{17}$

\section{Novel de novo mutation DNMT1p.P1546A: Immunodeficiency, narcolepsy, and developmental regression with myoclonus}

The case is currently aged 18 years and carries the novel DNMT1 mutation p.P1546A. This is the first mutation residing outside the TS domain. At 9-month checkup, he appeared having met early developmental milestones, including acquisition of multiple words. He soon, however, 
Case 1

II

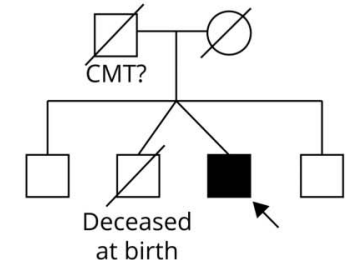

p.E510K

Case 4

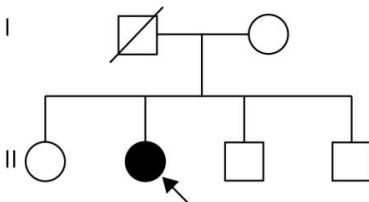

p.T497P
Case 2

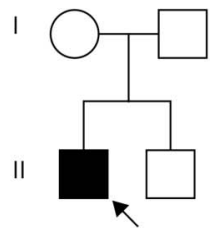

p.P1546A

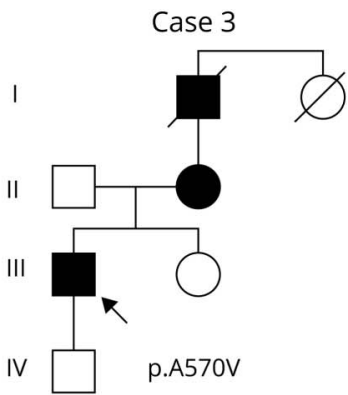

Case 5

$\square$ ○

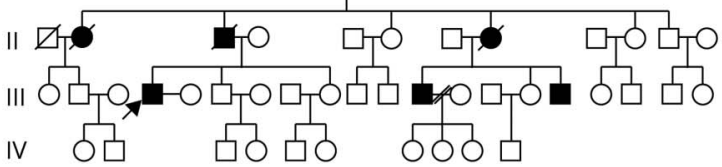

p.Y511H
The probands are indicated by black arrows. Other affected family cases are based on the family history and genetic testing information. Deceased cases are only based on the family history. regressed in language and stopped speaking. He exhibited episodes of eyelid fluttering around 10 months and subsequently generalized tonic-clonic seizures. The clinical and EEG findings suggested a diagnosis of Landau-Kleffner syndrome, for which he was treated with levetiracetam. By age 11 years, he developed both hypersomnolence and emotion- induced cataplexy lasting up to 2 minutes without epileptiform abnormality (Video 1, links.lww.com/NXG/A272). Initially, cataplexy occurred monthly, but became daily later. The case also developed action myoclonus. Polysomnogram testing showed REM sleep without atonia, REM behavior disorder (laughing and talking), and severe obstructive and

Figure 2 Brain MRI shows hemiatrophy and T2 hyperintesities and enhancement on postgadolinium T1-weighted sequences, DNMT1 p.A570V
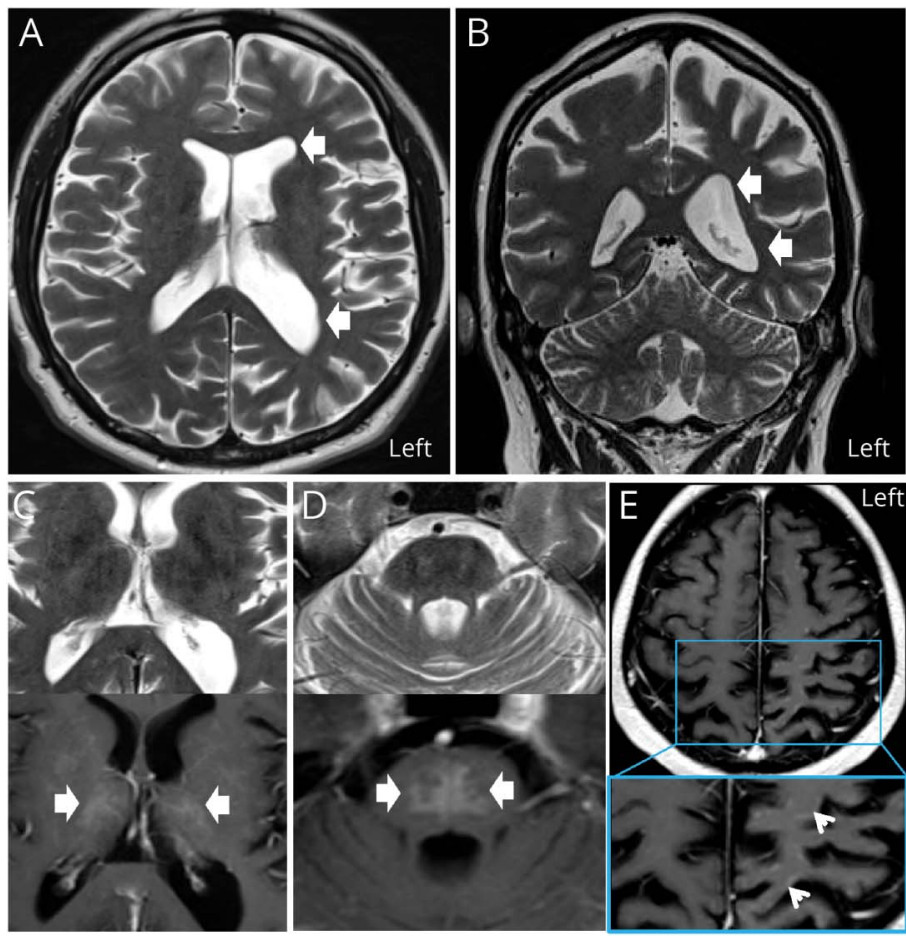

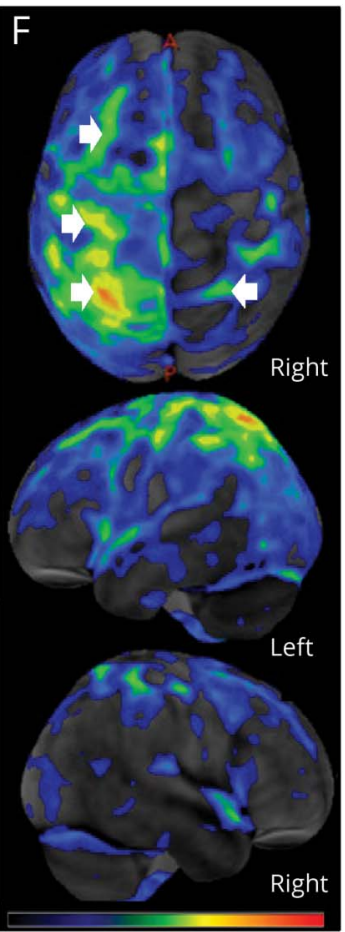

(A and B) Brain hemiatrophy (arrows) in this case with prolonged cataplectic events. (C-E) Abnormal T2 hyperintense signal in the brain cortex, basal ganglia, and brainstem (arrows) with enhancement postgadolinium (bottom). The T2 hyperintesity and enhancement is most prominent on the cortical surfaces. (E) Arrows are of T1 post gadolinium enhancement in areas of cortical atrophy. (F) Fluorodeoxyglucose-PET with signal normalized against the pons and converted to standardized z-scores demonstrating marked left brain hypometabolism (green: mild; yellow: moderate; and red: severe) in correlation with the brain atrophy. Arrows indicate regions of hyopometabolism. 
central sleep apnea. Hypersomnia did not improve with nocturnal bilevel positive airway pressure use. The case's family declined CSF orexin testing for narcolepsy diagnosis. Gait had been clumsy since the toddler years. By age 16 years, he needed a walker and started to show rapidly progressive hearing loss, requiring bilateral hearing aids. Around this time, his vision also declined, and fundoscopic examination revealed bilateral optic atrophy. At age 18 years, he uses a wheelchair, requiring total care with a gastrostomy tube placed due to aspiration. He has had chronic otitis, chronic sinusitis, recurrent pneumonias, and bronchiectasis since childhood. He was diagnosed with hypogammaglobulinemia with impaired specific antibody response and was treated with IV immunoglobulins (IVIGs).

Nerve conduction studies demonstrated an axonal sensory neuropathy. MRI showed generalized cerebellar and cortical atrophy with nonenhancing white matter T2 hyperintensities. The p.P1546A mutation is absent in all large genetic databases (gnomAD, 1000 Genomes, and EVS $)^{11-13}$ and is predicted to exert possibly damaging (PolyPhen-2), damaging (SIFT, FATHMM, and fathmm-MKL), deleterious (LRT), diseasecausing (MutationTaster) effect through in silico analysis with a CADD score of 25.1. ${ }^{14-16}$ Parental testing showed that the mutation had arisen de novo. No other potential causative mutations were identified by WES. This variant is classified as pathogenic variant. $^{17}$

\section{DNMT1 p.A570V: Hemi-brain atrophy and prolonged cataplectic attacks}

The case was referred to us at age 37 years with DNMT1 mutation p.A570V (c.1709C $>$ T) identified by whole-exome sequencing. ${ }^{6}$ This mutation is absent in large genetic databases (gnomAD, 1000 Genomes, and EVS) ${ }^{11-13}$ and shows probably damaging (PolyPhen-2), damaging (SIFT and fathmm-MKL), deleterious (LRT), disease-causing (MutationTaster) effect through in silico analysis with a CADD score of 29.1. ${ }^{14-16}$ This variant is classified as pathogenic variant. ${ }^{17}$ His first symptoms began at age 26 years when he fell; within seconds, his right leg was paralyzed and paresis spread to all 4 extremities. After this incident, he has experienced 1-2 events (paresis of limbs) per month induced by emotion stimuli, such as laughter, anger, or pain. The length of attacks lasts from minutes to several weeks and required hospitalizations. During the hospitalizations, perfusion and diffusion brain MRIs ruled out central ischemic events. Attacks were associated with speech arrest. Almost all attacks were characterized by asymmetric onset with right leg first and then extended to the arms. These episodes were captured by EEG with no epileptiform activity but mildly reduced amplitudes in interictal EEG wave forms and were felt to be consistent with cataplexy with possible status cataplectic events to explain his more prolonged episodes of weakness. He was HLA-DBQ $1^{*}$ 06:02 negative.

The case had brain MRIs 7 times from age 27 to 37 years, which showed progressive brain volume loss, many small foci of gadolinium enhancement involving cortical regions and bilateral cerebellum and basal ganglia, also confluent enhancement of the bilateral pons and bilateral thalami, figure 2 . EEG showed background slowing in the left hemispheric regions prominently that correlates with areas of hypometabolism by fluorodeoxyglucose-PET scan and atrophy of the left hemisphere on MRIs. His sleep testing was consistent with narcolepsy with 4 sleep-onset REM periods.

At age 37 years, he scored in the normal range on the Montreal Cognitive Assessment (28/30). However, neuropsychological testing showed executive dysfunction localizing to frontosubcortical and frontoparietal structures, consistent with poor organizational skills at home and work. He has increasingly been having difficulties at work due to somnolence and pseudobulbar effect. Audiometry at age 32 years was normal bilaterally, and nerve conduction study did not show evidence of polyneuropathy. However, hearing loss and peripheral sensory neuropathy tend to occur at later stages for ADCA-DN. ${ }^{6}$

\section{Cochlear implant dramatically improves hearing loss in DNMT1-complex disorder}

We have been following a previously reported case with de novo p.T497P mutation who is currently aged 39 years. DNMT1p.T497P mutation is absent in large genetic databases (gnomAD, 1000 Genomes, and EVS) ${ }^{11-13}$ and showed probably damaging (PolyPhen-2), damaging (SIFT, FATHMM, and fathmm-MKL), deleterious (LRT), diseasecausing (MutationTaster) effect through in silico analysis with a CADD score of $31 .^{14-16}$ This variant is classified as

Figure 3 Audiogram pre- and postcochlear implant DNMT1 p.T497P case

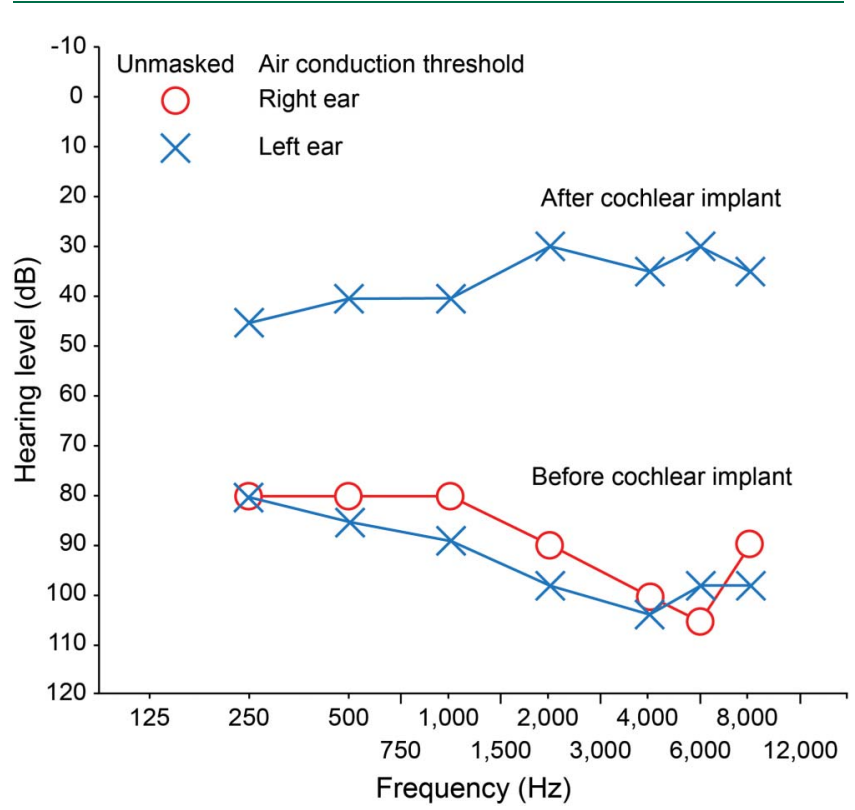

Marked improvement in hearing was demonstrated after left cochlear implant. 
pathogenic variant. ${ }^{17}$ She developed progressive hearing loss, axonal sensory neuropathy, memory decline, behavioral disturbance, hypersomnolence, and myoclonus, which all began in her early 20s. Hearing loss was an initial presenting feature and worsened over time. At age 38 years, her audiometry revealed bilateral severe sensorineural hearing loss (figure 3). In the best aided condition with a signal to noise ratio of $10 \mathrm{~dB}$ hearing level, the case has a speech perception score of $30 \%$. A left cochlear implant surgery was performed. She tolerated the stimulation levels and reported that she could hear the beeps. Two months after surgery, she started participating in conversations and reported to hear the neighbors' dog barking across the street, something she could not do previously. She also reported that her balance was improved. The audiograms showed dramatic improvement (figure 3), but her memory declines progressed, limiting the benefits of the procedure.

\section{DNMT1p.Y511H: Predominant spinal cord atrophy affecting the posterior column}

DNMT1p.Y511H mutation is absent in large genetic databases (gnomAD, 1000 Genomes, and EVS) $)^{11-13}$ and showed probably damaging (PolyPhen-2), damaging (SIFT, FATHMM, and fathmm-MKL), deleterious (LRT), diseasecausing (MutationTaster) effect through in silico analysis with a CADD score of $24.8 .^{14-16}$ This variant is classified as pathogenic variant. ${ }^{17}$ The 50 -year-old case developed bilateral sensorineural hearing loss in his mid-30s. By his mid-40s, he had symmetrical decrease of sensations below his knees with painless ulcers in both feet. At age 47 years, he failed to sense bone fracture on his toes, but did not have abnormalities in his hands. His cognition was only mildly affected by age 50 years with slight amnesia. His Mini-Mental State Examination score was 25/30 (Serial 7's 1/5, Recall 2/3) and Wechsler Adult Intelligence Scale-Third Edition (TIQ 76, VIQ 86, PIQ70). Frontal lobe dysfunction was prominent (inattention and decreased processing speed), but without behavioral or personality changes. Cerebellar examination was largely intact, but his heel to shin testing was impaired by severe proprioception deficit. Sural nerve sensory response was still present with normal median and ulnar sensory nerve action potentials. However, somatosensory evoked potential (SEP) was absent in lower extremity while the upper limbs were relatively normal. This SEP finding was in line with the spinal cord atrophy with posterior column degeneration on MRI (figure 4).

\section{Discussion}

To date, a total of 18 DNMT1 causal mutations (missense or small deletions) have been described, all within the TS domain of DNMT1. ${ }^{18}$ Herein, we identified 2 novel

Figure 4 Somatosensory defect of DNMT1 p.Y511H with sensory gait ataxia

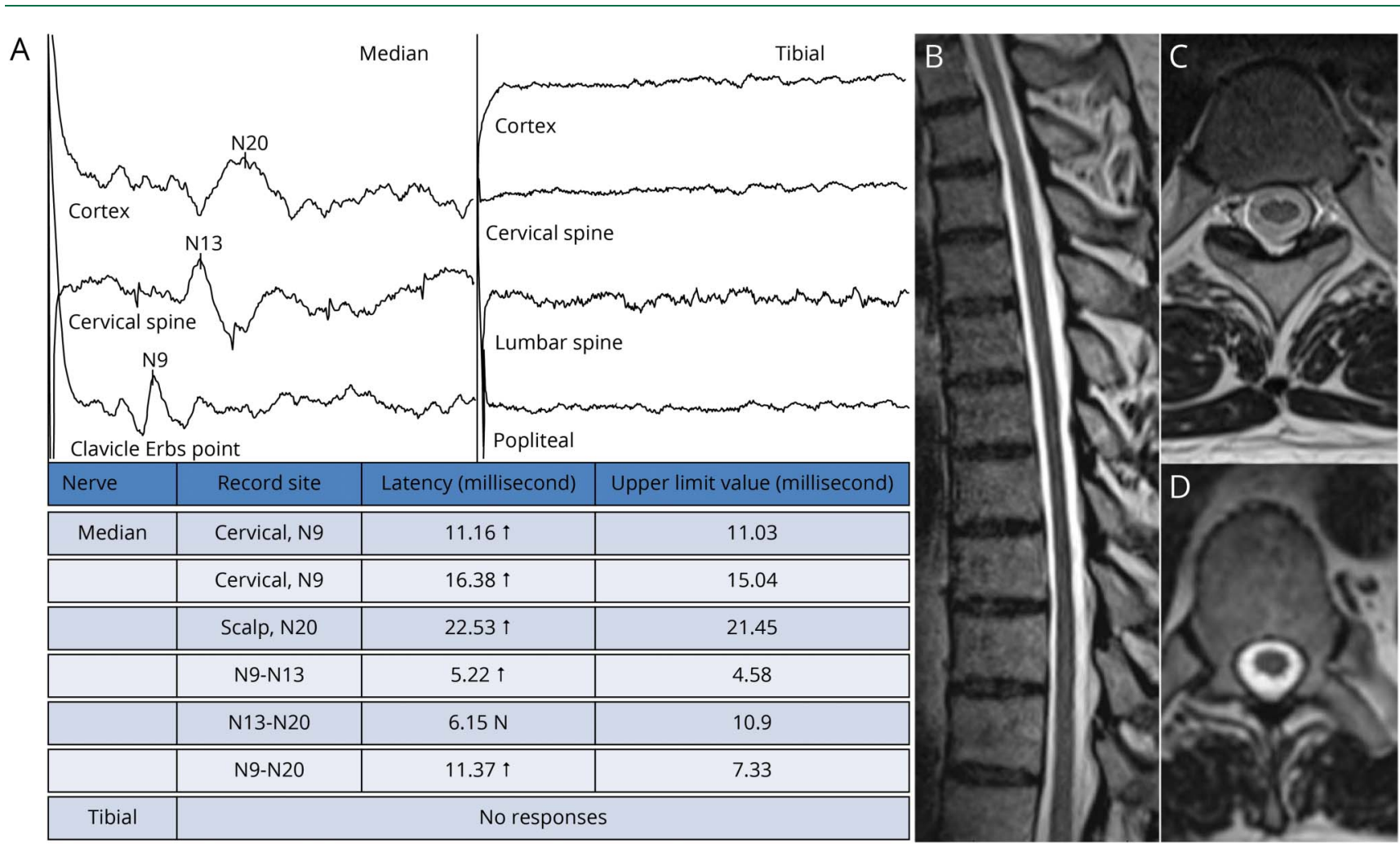

(A) The case showed profound gait ataxia and relatively preserved extremity sensory examination and absent tibial evoked potentials despite borderline sural sensory amplitude at $2 \mu \mathrm{V}$ with relative N9 to N13 prolongation and cortical prolongation recorded at median sensory. (B) Sagittal MRI of the spinal cord showing pronounced cord atrophy. (C and D) Most pronounced was the atrophy at thoracic levels shown on axial T1 and T2 images at the T10 spinal level. 
mutations of DNMT1 through WES, one of them is de novo and located outside of the TS domain (table). The range of our imaging and neurophysiologic data and cochlear implantation experience is valuable in not only diagnosis but also management of cases with DNMT1 mutations. Our study emphasizes that the highly variable phenotypes of DNMT1-complex disorder create significant challenges in clinical diagnosis, as illustrated by the fact that 3 of the 5 cases underwent WES to ascertain the diagnosis. The highly variable spectrum of clinical, pathologic, and electrophysiologic phenotypes demonstrates dynamics of focally afflicted neural tissues in each case. This demands a better understanding how these mutations interact with local tissue environments to the development of neural pathology in the disease, including also in children as demonstrated in this study.

Table Phenotypes and genetics of patients with DNMT1-related neurologic disorders

\begin{tabular}{|c|c|c|c|c|c|}
\hline Phenotype & Phenotypic features & $\begin{array}{l}\text { Nucleotide } \\
\text { change }\end{array}$ & $\begin{array}{l}\text { Protein } \\
\text { change }\end{array}$ & $\begin{array}{l}\text { Within } \\
\text { TS } \\
\text { domain }\end{array}$ & References \\
\hline $\begin{array}{l}\text { HSAN1E + varied } \\
\text { additional features }\end{array}$ & $\begin{array}{l}\text { Typical HSAN, + one with renal failure kidney atrophy, + } \\
\text { asymmetric leg lymphadenopathy }\end{array}$ & C.1106G>T & p.C369F & $\mathrm{Y}$ & Baets et al. ${ }^{7}$ \\
\hline $\begin{array}{l}\text { HSAN1E + } \\
\text { additional features }\end{array}$ & $\begin{array}{l}\text { Typical HSAN + prominent behavioral change initially confused } \\
\text { for schizophrenia, auditory and visual hallucinations }\end{array}$ & c. $1489 \mathrm{~A}>\mathrm{C}$ & p.T497P & $\mathrm{Y}$ & Baets et al. ${ }^{7}$ \\
\hline $\begin{array}{l}\text { HSAN1E + } \\
\text { additional features }\end{array}$ & $\begin{array}{l}\text { Typical HSAN, + daytime sleepiness without narcolepsy, + } \\
\text { elevated lactate after exercise and baseline }\end{array}$ & c. $1520 C>G$ & p.P507R & $\mathrm{Y}$ & $\begin{array}{l}\text { Moghadam } \\
\text { et al. }{ }^{9}\end{array}$ \\
\hline HSAN1E & Typical HSAN phenotype & c. $1520 C>T$ & p.P507L & $\mathrm{Y}$ & Baets et al. ${ }^{7}$ \\
\hline $\begin{array}{l}\text { HSAN1E + } \\
\text { additional features }\end{array}$ & Typical HSAN, + one with atonic spells & $\begin{array}{l}\text { c.1518 } \\
1520 \text { delTCC } \\
\text { ins ATA }\end{array}$ & $\begin{array}{l}\text { p.Asp506 } \\
\text { Pro507 del ins } \\
\text { GluTyr }\end{array}$ & $\mathrm{Y}$ & Klein et al. ${ }^{5}$ \\
\hline $\begin{array}{l}\text { ADCA-DN + } \\
\text { additional features }\end{array}$ & Typical ADCA-DN, + frequent tonic-clonic seizures & c. $1528 \mathrm{G}>\mathrm{A}$ & p.E510K & $\mathrm{Y}$ & $\begin{array}{l}\text { Current } \\
\text { report }\end{array}$ \\
\hline HSAN1E & Typical HSAN, FTD-like symptoms & c. $1532 A>G$ & p.Y511C & $\mathrm{Y}$ & Klein et al. ${ }^{5}$ \\
\hline HSAN1E & Typical HSAN, FTD-like symptoms & c. $1531 T>C$ & p.Y511H & Y & Klein et al. ${ }^{23}$ \\
\hline $\begin{array}{l}\text { ADCA-DN + varied } \\
\text { additional features }\end{array}$ & Typical ADCA-DN, + postural and action myoclonus & $\begin{array}{l}\text { c.1562_- } \\
\text { 1564delAGA }\end{array}$ & p.Lys521del & $\mathrm{Y}$ & $\begin{array}{l}\text { Moghadam } \\
\text { et al. }{ }^{9}\end{array}$ \\
\hline $\begin{array}{l}\text { HSAN1E + varied } \\
\text { additional features }\end{array}$ & $\begin{array}{l}\text { Typical HSAN in Chinese patient, + cerebellar ataxia and motor } \\
\text { plus sensory neuropathy }\end{array}$ & c. $1618 \mathrm{~T}>\mathrm{A}$ & p.Y540N & $\mathrm{Y}$ & Zheng et al. ${ }^{24}$ \\
\hline $\begin{array}{l}\text { HSAN1E + varied } \\
\text { additional features }\end{array}$ & Typical HSAN, + renal failure death 43 years old & c. $1618 T>G$ & p.Y540D & $\mathrm{Y}$ & Baets et al. ${ }^{7}$ \\
\hline $\begin{array}{l}\text { HSAN1E + varied } \\
\text { additional features }\end{array}$ & $\begin{array}{l}\text { Typical HSAN, + 8-year-old onset, atonic spells, cerebellar ataxia, } \\
\text { scleroderma, endocrinopathy, and common variable immune } \\
\text { deficiency }\end{array}$ & $\begin{array}{l}\text { c.1635 } \\
\text { 1637delCAA }\end{array}$ & p.Asn545del & $\mathrm{Y}$ & Fox et al. ${ }^{10}$ \\
\hline HSAN1E & Typical HSAN & c. $1640 \mathrm{~T}>\mathrm{A}$ & p.1547N & Y & Baets et al. ${ }^{7}$ \\
\hline HSAN1E & Typical HSAN in a Japanese patient & c. $1706 \mathrm{~A}>\mathrm{G}$ & p.H569R & $\mathrm{Y}$ & Yuan et al. ${ }^{25}$ \\
\hline $\begin{array}{l}\text { ADCA-DN + } \\
\text { additional features }\end{array}$ & Typical ADCA-DN, + lymphadenopathy & c. $1709 \mathrm{C}>\mathrm{T}$ & p.A570V & $\mathrm{Y}$ & $\begin{array}{l}\text { Winkelmann } \\
\text { et al. }{ }^{6}\end{array}$ \\
\hline $\begin{array}{l}\text { ADCA-DN + varied } \\
\text { additional features }\end{array}$ & Typical ADCA-DN, low CSF hypocretin, +HLA-DQB1 & c. $1786 \mathrm{~T}>\mathrm{C}$ & p.C596R & $\mathrm{Y}$ & $\begin{array}{l}\text { Pedroso } \\
\text { et al. }^{26}\end{array}$ \\
\hline ADCA-DN/HSAN1E & Common features of both ADCA-DN and HSAN1E & c. $1792 C>T$ & p.R598W & $\mathrm{Y}$ & $\begin{array}{l}\text { Catania } \\
\text { et al. }{ }^{27}\end{array}$ \\
\hline ADCA-DN & Typical ADCA-DN, + lymphadenopathy & c. $1814 \mathrm{G}>\mathrm{C}$ & p.G605A & $\mathrm{Y}$ & $\begin{array}{l}\text { Winkelmann } \\
\text { et al. }{ }^{6}\end{array}$ \\
\hline ADCA-DN & Typical ADCA-DN & c.1816 G>T & p.V606F & $\mathrm{Y}$ & $\begin{array}{l}\text { Winkelmann } \\
\text { et al. }{ }^{6}\end{array}$ \\
\hline $\begin{array}{l}\text { HSAN1E/ADCA-DN } \\
\text { and } \\
\text { immunodeficiency }\end{array}$ & $\begin{array}{l}\text { 9-month-old onset, cataplexy, narcolepsy, sensory neuropathy, } \\
\text { hearing loss, myoclonus, immunodeficiency, and optic atrophy }\end{array}$ & c. $4636 C>G$ & p.P1546A & $\mathrm{N}$ & $\begin{array}{l}\text { Current } \\
\text { report }\end{array}$ \\
\hline
\end{tabular}

Abbreviations: ADCA-DN = autosomal dominant cerebellar ataxia deafness and narcolepsy; HSAN1E = hereditary sensory and autonomic neuropathy $1 \mathrm{E}$ with sensory neuropathy, hearing loss, and cognitive involvement; TS = target sequence domain. 
The first novel DNMT1 mutation p.E510K locates next to the hot spot of Y511 (figure 5). This case had the triad of core symptoms of DNMT1-complex disorder. He also developed epilepsy with seizures and had rapid cognitive decline in his late 50s. His father and a paternal cousin (both deceased) also exhibited symptoms of Charcot-Marie-Tooth (CMT). We have seen that CMT diagnosis was initially given to cases with DNMT1-complex disorder, but broader clinical abnormalities developed later may prompt the utilization of WES. ${ }^{7}$ It remains to be possible that DNMT1 mutations may be present in more cases with CMT diagnosis because their early phenotype could be confined to the peripheral nerves.

All mutations reported to date that cause either HSAN1E or ADCA-DN are within the TS domain of DNMT1. We identified a novel de novo DNMT1 mutation p.P1546A (figure 5) outside of the TS domain. This is the first mutation identified within the catalytic domain of DNMT1. Besides the 3 core symptoms of DNMT1-complex disorder, the case presented a more complex phenotype. This case also displayed hypogammaglobulinemia, making this the second reported case with immune deficiency (the previously reported case carried the p.N545del mutation). The link between aberrant epigenetic regulation and immunodeficiency is well known. ${ }^{19}$ This case provides new insights that mutations in the catalytic domain of DNMT1 may exert a more deleterious effect, leading to early onset and complex phenotype.

The case 3 with p.A570V (figure 5) mutation is unique as no previous cases have had such prolonged cataplexy attacks, ${ }^{9}$ suggestive of status cataplectic events. The extensive enhancement without much signal abnormality on T2 or FLAIR resembled an inflammatory or perivenular process, leading to an early suspicion of an autoimmune disorder. IVIG and highdose pulse steroid treatment did not yield any improvements. His differential diagnoses included a demyelinating processes, low-grade lymphoma, vasculitis, and chronic lymphocytic inflammation with pontine perivascular enhancement responsive to steroids (CLIPPERS), ${ }^{20}$ which were all excluded by laboratory testing and follow-up clinical examinations. Cerebral hemiatrophy syndromes can present with variable neurologic symptoms including mitochondrial encephalopathy. Indeed, DNMT1 was shown involved in methylation of mitochondrial DNA ${ }^{21}$ and DNMT1-complex disorder shared common phenotypic traits of mitochondrial encephalomyopathies. Both cases 2 and 3 were tested negative for HLA$\mathrm{DBQ} 1^{*} 06: 02$, a genotype strongly associated with idiopathic narcolepsy.

Although the exact pathogenesis of deafness in cases with DNMT1 mutations is uncertain, it is likely the consequence of both cochlear and retrocochlear dysfunction. The hearing loss could stem from damage of sensory cells in the inner ear, or damage of the auditory nerve, or a combination of both. Whether cochlear implantation can significantly improve hearing loss due to DNMT1 mutation was not known previously. The case with DNMT1 p.T497P showed dramatic improvement after cochlear implantation surgery. Her experience also indicated that an early implantation before significant cognitive decline is likely to have more beneficial effects on quality of life.

DNMT1 p.Y511H was previously reported in 2 kindreds where both probands had prominent FTD-like symptoms with behavior and personality changes but without significant memory loss. ${ }^{22}$ The case 5 manifested with a severe sensory ataxia that localized primarily to posterior columns of the

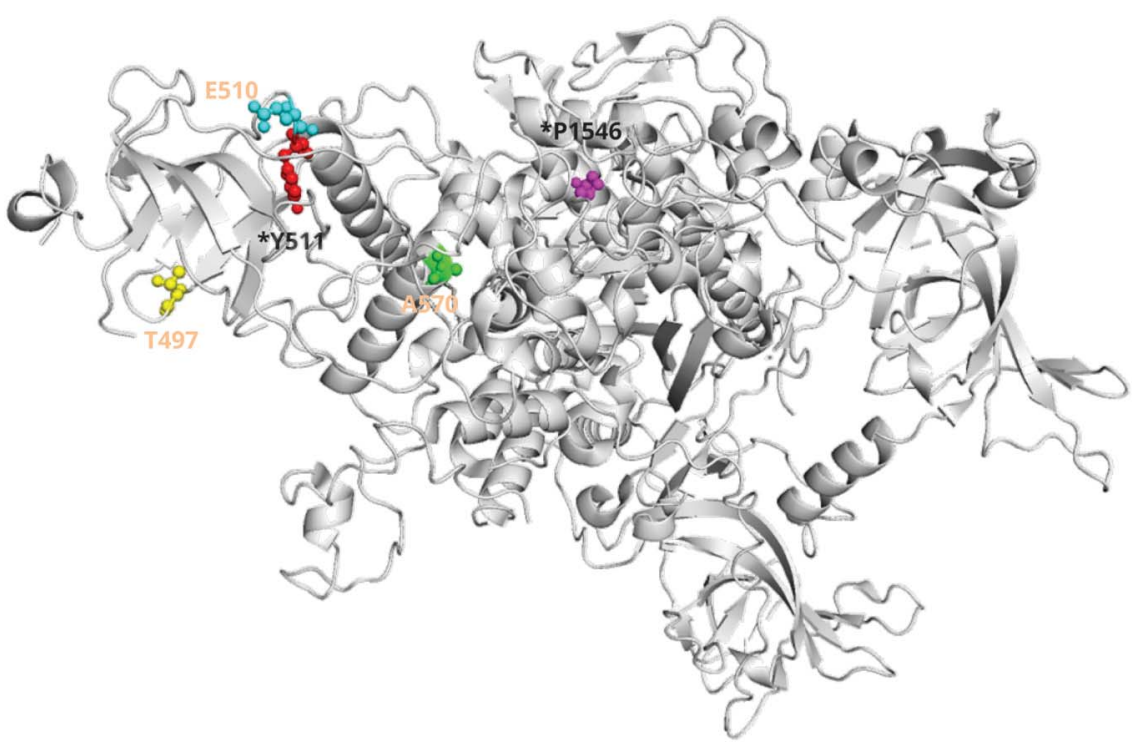

Cases with mutations at A570 and P1546 had cataplexy with narcolepsy. All mutations were within the targeting sequence domain except that $P 1546$ residing within the catalytic domain of DNMT1. 
spinal cord with largely preserved peripheral sensory nerve functioning. Of interest, results from his nerve conduction studies, SEPs, and spinal MRI indicated that his leg sensory abnormalities were primarily resulted from tractopathy originated from the central sensory pathways of the spinal cord instead of peripheral nerves.

Although cases with DNMT1 mutations are still rare, this study evidently expands the spectrum of phenotypes and emphasized the importance of WES application in complex disorders. Previously recognized as an adult-onset neurodegenerative disorder, we now learned that cases with DNMT1complex disorder can have young onset. Two new causal mutations were identified both with childhood onset and novel phenotypes. We also provided an intervention option for hearing loss in DNMT1-complex disorder. It is conceivable that more pathogenic DNMT1 mutations will be found in cases with complex phenotypes, which would also yield important insights how the methylation contributes to neural development and maintenance.

\section{Study funding}

This study was supported by the Center of Individualized Medicine, Mayo Clinic.

\section{Disclosure}

H. Bi, K. Hojo, M. Watanabe, C. Yee, K. Maski, and S. Saba report no disclosures. J. Graff-Radford reports NIH funding and receiving an honorarium from the American Academy of Neurology. M.M. Machulda, E.K. St Louis, and I. Spitsyna Humes report no disclosures. E.P. Flanagan is a site principal investigator in a randomized placebo-controlled clinical trial of Inebilizumab (A CD19 inhibitor) in neuromyelitis optica spectrum disorders funded by MedImmune/Viela Bio; he receives no personal compensation and just receives reimbursement for the research activities related to the trial. S. Nicolau and D.T. Jones report no disclosures. M.C. Patterson reports honoraria for consulting from Actelion, Agios, Amicus, IntraBio, Novartis, Orphazyme, Shire, and Vtesse; stock ownership in IntraBio; research funding from the NIH, Amicus (site principal investigator in an open-label study of pharmacokinetics, safety, efficacy, and pharmacodynamics of ATB200/AT2221 on pediatric subjects aged 12 to $<18$ years with late-onset pompe disease), Glycomine (site principal investigator for clinical and basic investigations into phosphomannomutase deficiency [PMM2-CDG]), Idorsia (site principal investigator of a natural history study for pediatric cases with early onset of either GM1 gangliosidosis, GM2 gangliosidosis, or Gaucher disease type 2 [RETRIEVE]), Orphazyme (site principal investigator in a placebocontrolled clinical trial of arimoclomol in Niemann-Pick disease, type C), and Shire/Takeda (site principal investigator for a global, multicenter, open-label, matched historical control study of intrathecal SHP611 in subjects with late infantile metachromatic leukodystrophy); stipends for editorial duties (Sage: Editor-in-Chief of the Journal of Child Neurology and Child Neurology Open; SSIEM: Editor for Journal of Inherited Metabolic Disease and JIMD Reports); and royalties (pediatric section editor for Up-To-Date). S. Kotagal, Y. Raz, and Z. Niu report no disclosures. Jun Li received honoraria from Alnylam and Neurogene for consultations. C.J. Klein received honoraria from Akcea for educational talks on TTR amyloid and Fabry disease and is a consultant to Pfizer Pharmaceuticals, but receives no personal compensation for his work. Go to Neurology.org/ NG for full disclosures.

\section{Publication history}

Received by Neurology: Genetics January 21, 2020. Accepted in final form April 30, 2020.

Appendix Authors

\begin{tabular}{|c|c|c|}
\hline Name & Location & Contribution \\
\hline $\begin{array}{l}\text { Hongyan Bi, } \\
\text { MD }\end{array}$ & $\begin{array}{l}\text { Mayo Clinic, Rochester, } \\
\text { MN; Beijing Friendship } \\
\text { Hospital, Beijing, China }\end{array}$ & $\begin{array}{l}\text { Designed and } \\
\text { conceptualized the study; } \\
\text { analyzed the data; and } \\
\text { drafted the manuscript for } \\
\text { intellectual content }\end{array}$ \\
\hline $\begin{array}{l}\text { Kaori Hojo, } \\
\text { MD }\end{array}$ & $\begin{array}{l}\text { Neuropsychiatry, Harima } \\
\text { Sanatorium, Hyogo, Japan }\end{array}$ & $\begin{array}{l}\text { Major role in the } \\
\text { acquisition of data and } \\
\text { revised the manuscript for } \\
\text { intellectual content }\end{array}$ \\
\hline $\begin{array}{l}\text { Masashi } \\
\text { Watanabe, } \\
\text { MD }\end{array}$ & $\begin{array}{l}\text { Neurology, Ehime } \\
\text { Prefectural Central } \\
\text { Hospital, Matsuyama, } \\
\text { Japan }\end{array}$ & $\begin{array}{l}\text { Major role in the } \\
\text { acquisition of data and } \\
\text { revised the manuscript for } \\
\text { intellectual content }\end{array}$ \\
\hline $\begin{array}{l}\text { Christina } \\
\text { Yee, MD }\end{array}$ & $\begin{array}{l}\text { Harvard Medical School, } \\
\text { Boston Children's Hospital, } \\
\text { MA }\end{array}$ & $\begin{array}{l}\text { Major role in the } \\
\text { acquisition of data and } \\
\text { revised the manuscript for } \\
\text { intellectual content }\end{array}$ \\
\hline $\begin{array}{l}\text { Kiran Maski, } \\
\text { MD }\end{array}$ & $\begin{array}{l}\text { Harvard Medical School, } \\
\text { Boston Children's Hospital, } \\
\text { MA }\end{array}$ & $\begin{array}{l}\text { Major role in the } \\
\text { acquisition of data and } \\
\text { revised the manuscript for } \\
\text { intellectual content }\end{array}$ \\
\hline
\end{tabular}

\begin{tabular}{lll}
\hline $\begin{array}{l}\text { Sadaf Saba, } \\
\text { MS }\end{array}$ & $\begin{array}{l}\text { Center for Molecular } \\
\text { Medicine and Genetics, } \\
\text { School of Medicine, Wayne } \\
\text { State University, Detroit, MI }\end{array}$ & $\begin{array}{l}\text { Major role in the } \\
\text { acquisition of data and } \\
\text { revised the manuscript for } \\
\text { intellectual content }\end{array}$ \\
\hline $\begin{array}{l}\text { Jonathan } \\
\text { Graff- } \\
\text { Radford, MD }\end{array}$ & $\begin{array}{l}\text { Department of Neurology, } \\
\text { Mayo Clinic, Rochester, MN }\end{array}$ & $\begin{array}{l}\text { Major role in the } \\
\text { acquisition of data and } \\
\text { revised the manuscript for } \\
\text { intellectual content }\end{array}$ \\
\hline
\end{tabular}

\begin{tabular}{lll}
\hline Mary M. & Department of Psychology, \\
Machulda, & Mayo Clinic, Rochester, MN & $\begin{array}{l}\text { Major role in the } \\
\text { acquisition of data and } \\
\text { PhD }\end{array}$ \\
& $\begin{array}{l}\text { revised the manuscript for } \\
\text { intellectual content }\end{array}$
\end{tabular}

\begin{tabular}{lll}
\hline Erik K. St & Department of Neurology, \\
Louis, MD & Mayo Clinic, Rochester, MN & $\begin{array}{l}\text { Major role in the } \\
\text { acquisition of data and } \\
\text { revised the manuscript for } \\
\text { intellectual content }\end{array}$
\end{tabular}

\begin{tabular}{lll}
\hline $\begin{array}{l}\text { Ilona } \\
\text { Spitsyna } \\
\text { Humes, MD }\end{array}$ & $\begin{array}{l}\text { Atrium Health, } \\
\text { Neurosciences Institute, } \\
\text { Concord, NC }\end{array}$ & $\begin{array}{l}\text { Major role in the } \\
\text { acquisition of data and } \\
\text { revised the manuscript for } \\
\text { intellectual content }\end{array}$ \\
\hline $\begin{array}{l}\text { Eoin P. } \\
\begin{array}{l}\text { Flanagan, } \\
\text { MB BCh }\end{array}\end{array}$ & $\begin{array}{l}\text { Department of Neurology, } \\
\text { Mayo Clinic, Rochester, MN }\end{array}$ & $\begin{array}{l}\text { Major role in the } \\
\text { acquisition of data and } \\
\text { revised the manuscript for } \\
\text { intellectual content }\end{array}$ \\
\hline
\end{tabular}


Appendix (continued)

\begin{tabular}{lll}
\hline Name & Location & Contribution \\
\hline $\begin{array}{ll}\text { Stefan } \\
\text { Nicolau, MD }\end{array}$ & $\begin{array}{l}\text { Department of Neurology, } \\
\text { Mayo Clinic, Rochester, MN }\end{array}$ & $\begin{array}{l}\text { Major role in the } \\
\text { acquisition of data and } \\
\text { revised the manuscript for } \\
\text { intellectual content }\end{array}$
\end{tabular}

\begin{tabular}{ll}
\hline David T. & Department of Neurology, \\
Jones, MD & Mayo Clinic, Rochester, MN
\end{tabular}

Major role in the acquisition of data and revised the manuscript for intellectual content

\begin{tabular}{ll}
\hline Marc C. & Department of Neurology, \\
Patterson, & Mayo Clinic, Rochester, MN \\
MD &
\end{tabular}

Major role in the acquisition of data and revised the manuscript for intellectual content

Suresh Department of Neurology,

Major role in the

Kotagal, MD Mayo Clinic, Rochester, MN

acquisition of data and revised the manuscript for intellectual content

\begin{tabular}{|c|c|c|}
\hline Yael Raz, MD & $\begin{array}{l}\text { Deapartmen of Head and } \\
\text { Neck Surgery, Oregon } \\
\text { Health and Science } \\
\text { University, Portland }\end{array}$ & $\begin{array}{l}\text { Major role in the } \\
\text { acquisition of data and } \\
\text { revised the manuscript for } \\
\text { intellectual content }\end{array}$ \\
\hline $\begin{array}{l}\text { Zhiyv Niu, } \\
\text { PhD }\end{array}$ & $\begin{array}{l}\text { Department of Laboratory } \\
\text { Medicine and Pathology, } \\
\text { Mayo Clinic, Rochester, MN }\end{array}$ & $\begin{array}{l}\text { Major role in the } \\
\text { acquisition of data and } \\
\text { revised the manuscript for } \\
\text { intellectual content }\end{array}$ \\
\hline Jun Li, MD & $\begin{array}{l}\text { Department of Neurology } \\
\text { and Translational } \\
\text { Neuroscience Initiative, } \\
\text { School of Medicine Wayne } \\
\text { State University, Detroit, MI }\end{array}$ & $\begin{array}{l}\text { Major role in the } \\
\text { acquisition of data and } \\
\text { revised the manuscript for } \\
\text { intellectual content }\end{array}$ \\
\hline $\begin{array}{l}\text { Christopher } \\
\text { J. Klein, MD }\end{array}$ & $\begin{array}{l}\text { Department of Neurology, } \\
\text { Mayo Clinic, Rochester, MN }\end{array}$ & $\begin{array}{l}\text { Designed and } \\
\text { conceptualized the study; } \\
\text { analyzed the data; drafted } \\
\text { the manuscript for } \\
\text { intellectual content; } \\
\text { supervised the work; and } \\
\text { obtained funding for the } \\
\text { work }\end{array}$ \\
\hline
\end{tabular}

\section{References}

1. Yen RW, Vertino PM, Nelkin BD, et al. Isolation and characterization of the cDNA encoding human DNA methyltransferase. Nucleic Acids Res 1992;20:2287-2291.

2. Hermann A, Goyal R, Jeltsch A. The Dnmt1 DNA-(cytosine-C5)-methyltransferase methylates DNA processively with high preference for hemimethylated target sites. J Biol Chem 2004;279:48350-48359.

3. Klein C. Targeting sequence domain: a captain at the helm precisely steering DNMT1 through maintenance methylation? Epigenomics 2016;8:737-740.
4. Klein CJ, Benarroch EE. Epigenetic regulation: basic concepts and relevance to neurologic disease. Neurology 2014;82:1833-1840.

5. Klein CJ, Botuyan MV, Wu Y, et al. Mutations in DNMT1 cause hereditary sensory neuropathy with dementia and hearing loss. Nat Genet 2011;43:595-600.

6. Winkelmann J, Lin L, Schormair B, et al. Mutations in DNMT1 cause autosomal dominant cerebellar ataxia, deafness and narcolepsy. Hum Mol Genet 2012;21: 2205-2210.

7. Baets J, Duan X, Wu Y, et al. Defects of mutant DNMT1 are linked to a spectrum of neurological disorders. Brain 2015;138:845-861.

8. Klein C, Bird T, Ertekin-Taner N, et al. DNMT1 mutation hot spot causes varied phenotypes of HSAN1 with dementia and hearing loss. Neurology 2013;80:824-828.

9. Moghadam KK, Pizza F, La Morgia C, et al. Narcolepsy is a common phenotype in HSAN IE and ADCA-DN. Brain 2014;137:1643-1655.

10. Fox R, Ealing J, Murphy H, Gow DP, Gosal D. A novel DNMT1 mutation associated with early onset hereditary sensory and autonomic neuropathy, cataplexy, cerebellar atrophy, scleroderma, endocrinopathy, and common variable immune deficiency. J Peripher Nerv Syst 2016;21:150-153.

11. Available at: genome aggregation database. gnomad.broadinstitute.org/.

12. Genomes Project C, Auton A, Brooks LD, et al. A global reference for human genetic variation. Nature 2015;526:68-74.

13. Exome Variant Server. NHLBI GO Exome Sequencing Project (ESP). Seattle: EVS evs.gs.washington.edu/EVS/.

14. Adzhubei I, Jordan DM, Sunyaev SR. Predicting functional effect of human missense mutations using PolyPhen-2. Curr Protoc Hum Genet 2013; Chapter 7:Unit7 20.

15. Ng PC, Henikoff S. SIFT: predicting amino acid changes that affect protein function Nucleic Acids Res 2003;31:3812-3814.

16. Schwarz JM, Cooper DN, Schuelke M, Seelow D. MutationTaster2: mutation prediction for the deep-sequencing age. Nat Methods 2014;11:361-362.

17. Richards S, Aziz N, Bale S, et al. Standards and guidelines for the interpretation of sequence variants: a joint consensus recommendation of the American College of Medical Genetics and Genomics and the Association for Molecular Pathology. Genet Med 2015; 17:405-424.

18. Klein CJ. DNMT1-related disorder. In: Adam MP, Ardinger HH, Pagon RA, et al., eds. GeneReviews. Seattle: University of Washington, Seattle; 1993.

19. Hansen RS, Wijmenga C, Luo P, et al. The DNMT3B DNA methyltransferase gene is mutated in the ICF immunodeficiency syndrome. Proc Natl Acad Sci USA 1999;96: 14412-14417.

20. Pittock SJ, Debruyne J, Krecke KN, et al. Chronic lymphocytic inflammation with pontine perivascular enhancement responsive to steroids (CLIPPERS). Brain 2010; 133:2626-2634.

21. Saini SK, Mangalhara KC, Prakasam G, Bamezai RNK. DNA methyltransferase (DNMT1) Isoform 3 methylates mitochondrial genome and modulates its biology. Sci Rep 2017;7:1525

22. Klein CJ, Botuyan MV, Wu Y, et al. Mutations in DNMT1 cause hereditary sensory neuropathy with dementia and hearing loss. Nat Genet 2011;43:595-600.

23. Klein CJ, Bird T, Ertekin-Taner N, et al. DNMT1 mutation hot spot causes varied phenotypes of HSAN1 with dementia and hearing loss. Neurology 2013;80: 824-828

24. Zheng W, Yan Z, He R, et al. Identification of a novel DNMT1 mutation in a Chinese patient with hereditary sensory and autonomic neuropathy type IE. BMC Neurol 2018; 18:174.

25. Yuan J, Higuchi Y, Nagado T, et al. Novel mutation in the replication focus targeting sequence domain of DNMT1 causes hereditary sensory and autonomic neuropathy IE. J Peripher Nerv Syst 2013;18:89-93.

26. Pedroso JL, Povoas Barsottini OG, Lin L, Melberg A, Oliveira AS, Mignot E. A novel de novo exon 21 DNMT1 mutation causes cerebellar ataxia, deafness, and narcolepsy in a Brazilian patient. Sleep 2013;36:1257-1259, 1259A.

27. Catania A, Peverelli L, Tabano S, Ghezzi D, Lamperti C. DNMT1-complex disorder caused by a novel mutation associated with an overlapping phenotype of autosomaldominant cerebellar ataxia, deafness, and narcolepsy (ADCA-DN) and hereditary sensory neuropathy with dementia and hearing loss (HSN1E). Neurol Sci 2019;40: 1963-1966. 




Expanded genetic insight and clinical experience of DNMT1-complex disorder Hongyan Bi, Kaori Hojo, Masashi Watanabe, et al. Neurol Genet 2020;6;

DOI 10.1212/NXG.0000000000000456

This information is current as of June 12, 2020

Neurol Genet is an official journal of the American Academy of Neurology. Published since April 2015, it is an open-access, online-only, continuous publication journal. Copyright Copyright $\odot 2020$ The Author(s). Published by Wolters Kluwer Health, Inc. on behalf of the American Academy of Neurology.. All rights reserved. Online ISSN: 2376-7839.

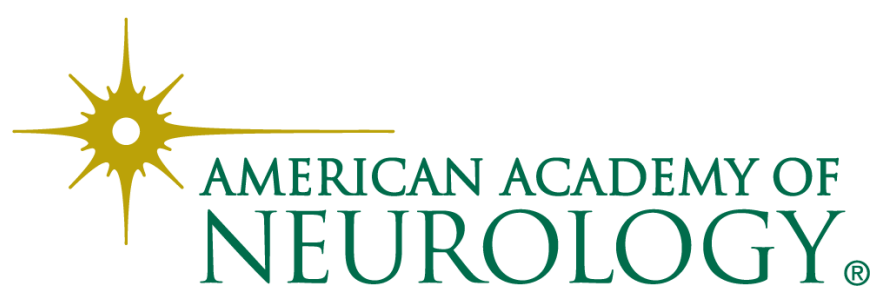




\section{Updated Information \& Services}

References

Subspecialty Collections

Permissions \& Licensing

\section{Reprints}

including high resolution figures, can be found at: http://ng.neurology.org/content/6/4/e456.full.html

This article cites 24 articles, 2 of which you can access for free at: http://ng.neurology.org/content/6/4/e456.full.html\#\#ref-list-1

This article, along with others on similar topics, appears in the following collection(s):

\section{All Genetics}

http://ng.neurology.org//cgi/collection/all_genetics

All Imaging

http://ng.neurology.org//cgi/collection/all_imaging

All Neuropsychology/Behavior

http://ng.neurology.org//cgi/collection/all_neuropsychology_behavior All Spinal Cord

http://ng.neurology.org//cgi/collection/all_spinal_cord

\section{Peripheral neuropathy}

http://ng.neurology.org//cgi/collection/peripheral_neuropathy

Information about reproducing this article in parts (figures,tables) or in its entirety can be found online at:

http://ng.neurology.org/misc/about.xhtml\#permissions

Information about ordering reprints can be found online:

http://ng.neurology.org/misc/addir.xhtml\#reprintsus

Neurol Genet is an official journal of the American Academy of Neurology. Published since April 2015, it is an open-access, online-only, continuous publication journal. Copyright Copyright $\odot 2020$ The Author(s). Published by Wolters Kluwer Health, Inc. on behalf of the American Academy of Neurology.. All rights reserved. Online ISSN: 2376-7839.

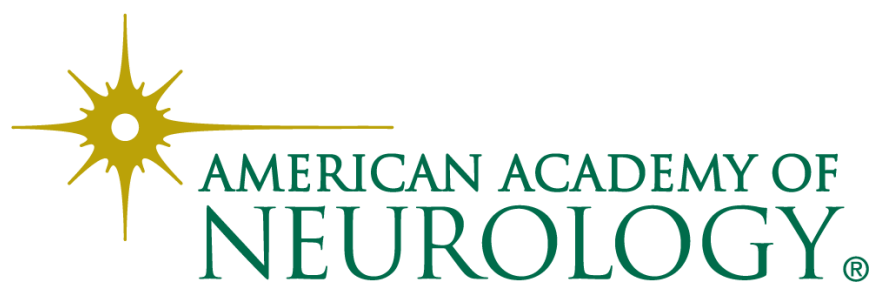

